\title{
Peningkatan Keaktifan Bertanya Melalui Model Inkuiri Terbimbing Tema Panas dan Perpindahannya pada Siswa Kelas V SD Negeri 3 Wonosari Tahun Ajaran 2018/2019
}

\section{Peni Setyorini ${ }^{1}$, Kartika Chrysti Suryandari ${ }^{2}$, Ngatman $^{3}$}

1,2,3 Universitas Sebelas Maret

peni.setyorini21@gmail.com

Article History

accepted 01/10/2019

approved 01/11/2019

published 01/12/2019

\begin{abstract}
This study aimed to increase the activeness of questioning through the guided inquiry model on the theme of Heat and Its Transfer in the fifth grade students of SD Negeri 3 Wonosari in Academic Year 2018/2019. This study was a collaborative classroom action research (PTK) between researchers and fifth grade students of SD Negeri 3 Wonosari conducted in three cycles with details of two meetings for each cycle. The subjects of this study were teachers and students of grafe $V$, totalling 25 students of 16 male students and 9 female students. Data collection techniques included test, observation, interview, and documentation. Data analysis techniques used technical triangulation and source triangulation. Analysis of quantitative and qualitative data included data reduction, data presentation, conclusion drawing/verification. The results of this study indicated that guided inquiry could increase the activeness of questioning on the theme of Heat and Its Transfer of grade V students of SD Negeri 3 Wonosari.
\end{abstract}

Keywords: activeness of questioning, guided inquiry, theme of Heat and Its Transfer

\begin{abstract}
Abstrak
Penelitian ini bertujuan untuk meningkatkan keaktifan bertanya melalui model inkuiri terbimbing tema Panas dan Perpindahannya pada siswa kelas V SD Negeri 3 Wonosari tahun ajaran 2018/2019. Penelitian ini adalah penelitian tindakan kelas (PTK) kolaboratif antara peneliti dengan guru kelas V SD Negeri 3 Wonosari yang dilakukan dalam tiga siklus dengan rincian dua pertemuan untuk setiap siklusnya. Subjek penelitian ini adalah guru dan siswa kelas $V$ yang berjumlah 25 siswa dengan rincian 16 siswa laki-laki dan 9 siswa perempuan. Teknik pengumpulan data adalah dengan tes, observasi, wawancara, dan dokumentasi. Teknik analisis data menggunakan triangulasi teknik dan triangulasi sumber. Analisis data kuantitatif dan kualitatif meliputi reduksi data, penyajian data, penarikan kesimpulan/ verifikasi. Hasil penelitian ini menunjukkan bahwa inkuiri terbimbing dapat meningkatkan keaktifan bertanya pada tema Panas dan Perpindahannya kelas V SD negeri 3 Wonosari.
\end{abstract}

Kata kunci: keaktifan bertanya, inkuiri terbimbing, tema Panas dan Perpindahannya 


\section{PENDAHULUAN}

Pada masa sekarang ini, kurikulum yang digunakan dalam pembelajaran mulai dari SD, SMP, dan SMA menggunakan kurikulum 2013. Pembelajaran dengan menggunakan kurikulum 2013 merupakan pem-belajaran yang berpusat pada siswa. Kurikulum tersebut digunakan untuk menunjang abad 21 yang memiliki empat keterampilan yang dikenal dengan istilah $4 C$ yaitu communication, collaboration, critical thingking and problem solving, serta creativity and innovation. Salah satu keterampilan pada abad 21 yaitu berpikir kritis. Menurut Amir (2015:162) berpikir kritis merupakan kegiatan yang dilakukan oleh seseorang dalam mengumpulkan, mengkategorikan, menganalisa, dan mengevaluasi informasi untuk membuat simpulan yang digunakan untuk memecahkan masalah.

Berpikir kritis dapat ditunjukkan siswa dengan bertanya. Rusman (2014:195) menyatakan bahwa pertanyaan merupakan permulaan dari pengetahuan yang dimiliki oleh seseorang sehingga dengan bertanya maka pembelajaran menjadi lebih bermakna. Sejalan dengan pendapat tersebut, Sagala (2014:88) menyatakan bahwa aktivitas bertanya berguna untuk mencari informasi, membangkitkan respon siswa, memeriksa rasa ingin tahu dan pemahaman siswa, memusatkan perhatian, membangkitkan siswa untuk bertanya, dan untuk menyegarkan pengetahuan siswa.

Berdasarkan manfaat bertanya yang telah dikemukakan di atas, maka dapat diketahui bahwa manfaat bertanya yaitu mencari informasi, memeriksa pengetahuan, me-ngembangkan respon, mengetahui rasa ingin tahu siswa, memfokuskan perhatian siswa dan menyegarkan pengetahuan.

Berdasarkan observasi yang dilakukan di SD Negeri 3 Wonosari pada tanggal 8 dan 9 November 2018 menunjukkan adanya kondisi sebagai berikut: (1) proses pembelajaran berpusat pada guru (2) siswa kurang aktif, terutama dalam kegiatan keaktifan bertanya kepada guru (3) siswa hanya mendengar dan mencatat hal-hal yang disampaikan guru (4) guru masih menggunakan model pembelajaran konvensional sehingga siswa kurang aktif bertanya (5) hasil belajar siswa kelas $\mathrm{V}$ masih tergolong rendah.

Berdasarkan kondisi pem-belajaran yang terjadi di kelas V SD Negeri 3 Wonosari maka perlu adanya perbaikan dalam pembelajaran. Salah satu solusi yang dapat dilakukan untuk memecahkan masalah di atas yaitu menerapkan model pembelajaran yang dapat meningkatkan keaktifan bertanya dan hasil belajar. Menurut peneliti inkuiri terbimbing dapat digunakan di SD Wonosari 3. Majid (2017:222) menyatakan bahwa "Model pem-belajaran inkuiri merupakan rangkaian kegiatan pembelajaran yang menekankan pada proses berpikir kritis dan analisis untuk mencari dan menemukan dari suatu masalah yang dipertanyakan". Sejalan dengan pendapat tersebut Hapsari, Sudarisman, dan Marjono (2012:18) menyatakan bahwa inkuiri terbimbing akan membuat siswa berpikir kritis karena siswa mengenali masalah, menyelidiki jawaban dan membuat kesimpulan.

Adapun langkah-langkah penerapan model inkuiri terbimbing menurut Metaputri, Margunayasa, Garminah (2016:7) diawali dengan guru menyajikan masalah, siswa menentukan rumusan masalah, menentukan jawaban sementara, mengumpulkan data dari buku-buku dan percobaan, dan membuat kesimpulan.

Model inkuiri terbimbing memberikan manfaat bagi siswa yaitu Anam (2016: 15) menyatakan bahwa kelebihan dari model pembelajaran inkuiri meliputi: 1) mendorong siswa untuk melakukan; 2) siswa belajar lebih banyak melalui berbagai macam sumber; 3) siswa menjadi pembelajar yang aktif karena menggunakan semua potensi pada diri siswa untuk berkreasi dan berinovasi; 4) siswa berpeluang melakukan penemuan atas observasi dan eksperimen untuk mendapatkan hasil materi yang dipelajari. 
Rumusan masalah dalam penelitian ini yaitu: apakah model inkuiri terbimbing dapat meningkatan keaktifan bertanya tema Panas dan Perpindahannya pada siswa kelas V SD Negeri 3 Wonosari tahun ajaran 2018/2019?

Tujuan penelitian ini adalah: peningkatan keaktifan bertanya tema Panas dan Perpindahannya pada siswa kelas V SD Negeri 3 Wonosari tahun ajaran 2018/2019 melalui model inkuiri terbimbing.

\section{METODE}

Penelitian ini merupakan penelitian tindakan kelas (PTK) kolaboratif antara peneliti dengan guru kelas V SD Negeri 3 Wonosari tahun ajaran 2018/2019. Penelitian dilaksanakan selama tiga siklus dengan rincian dua pertemuan untuk setiap siklus. Subjek penelitian ini adalah guru dan siswa kelas $V$ yang berjumlah 25 siswa dengan rincian 16 siswa laki-laki dan 9 siswa perempuan. Data yang digunakan berupa data kualitatif yaitu penerapan inkuiri terbimbing dan keaktifan bertanya siswa. Data kuantitatif yaitu jumlah siswa yang bertanya. Sumber data dalam penelitian ini yaitu guru, siswa, dan dokumen. Teknik pengumpulan data yaitu dengan tes, observasi, wawancara, dan dokumentasi. menggunakan triangulasi teknik dan sumber. Analisis data kuantitatif dan kualitatif meliputi reduksi data, penyajian data, penarikan kesimpulan/verifikasi Sugiyono (2017:246).

Indikator kinerja penelitian ini adalah peningkatan keaktifan bertanya dengan ketercapaian $85 \%$. Penelitian ini menggunakan prosedur penelitian yang terdiri dari perencanaan, pelaksanaan, pengamatan, dan refleksi (Arikunto,2013:137).

\section{HASIL DAN PEMBAHASAN}

Penelitian ini dilaksanakan dengan menerapkan langkah inkuiri terbimbing yaitu: (1) orientasi, (2) merumuskan masalah, (3) merumuskan hipotesis, (4) mengumpulkan data, (5) menguji hipotesis, dan (6) menyimpulkan.

Hasil observasi penerapan model inkuiri terbimbing terhadap guru dan siswa mengalami peningkatan pada setiap siklusnya dan mencapai indikator kinerja penelitian yaitu $85 \%$.

Tabel 1. Hasil Pengamatan Penerapan Model Inkuri Terbimbing terhadap Guru dan Siswa Siklus I, II, dan III

\begin{tabular}{llll}
\hline Persentas & \multicolumn{3}{l}{ Siklus } \\
e $(\%)$ & I & II & III \\
\hline Guru & 70,60 & 83,16 & 91,24 \\
Siswa & 64,52 & 77,27 & 89,31 \\
\hline
\end{tabular}

Berdasarkan tabel 1, persentase hasil pengamatan penerapan model inkuiri terbimbing terhadap guru meningkat dari siklus I-III antara 70,60\%-91,24\%. Terhadap siswa juga mengalami peningkatan mulai siklus I-III antara 64,52\%-89,31\%.Berikut ini merupakan hasil observasi keaktifan bertanya siswa siklus I-III.

Tabel 2. Hasil Observasi Keaktifan Bertanya Siklus I, II, dan III

\begin{tabular}{lccl}
\hline $\begin{array}{l}\text { Indikator } \\
\text { Bertanya }\end{array}$ & SI (\%) & SII (\%) & $\begin{array}{l}\text { SIII } \\
(\%)\end{array}$ \\
\hline Kesadaran & 65,50 & 77,60 & 87,20 \\
Tanggungjawab & 67,20 & 75,20 & 85,60 \\
Keberanian & 66,40 & 79,20 & 87,20 \\
Keterampilan & 62,40 & 75,50 & 85,60 \\
Inovasi & 62,40 & 76,00 & 87,20 \\
Kreativitas & 62,40 & 77,60 & 86,40 \\
Rata-rata & 64,38 & 76,85 & 86,53 \\
\hline
\end{tabular}


Berdasarkan tabel 2 dapat diketahui bahwa keaktifan bertanya aspek kesadaran meningkat dari siklus I yaitu $64,38 \%$, siklus II $76,85 \%$ dan $86,53 \%$ pada siklus III.

Selain hasil observasi tersebut, dapat diketahui juga intensitas bertanya siswa dari siklus I-III sebagai berikut.

Tabel 3. Intensitas Keaktifan Bertanya Siswa Siklus I, II, dan III

\begin{tabular}{llll}
\hline $\begin{array}{l}\text { Intensias } \\
\text { Bertanya }\end{array}$ & $\begin{array}{l}\text { Siklus } \\
\text { I }\end{array}$ & $\begin{array}{l}\text { Siklus } \\
\text { II }\end{array}$ & $\begin{array}{l}\text { Siklus } \\
\text { III }\end{array}$ \\
\hline$>6$ & 2 & 4 & 8 \\
5 & 3 & 6 & 8 \\
4 & 2 & 3 & 4 \\
3 & 1 & 3 & 2 \\
2 & 3 & 2 & 1 \\
1 & 6 & 2 & 1 \\
0 & 8 & 5 & 1 \\
\hline
\end{tabular}

Berdasarkan tabel 3 dapat diketahui bahwa intensitas siswa bertanya siswa pada siklus I dengan jumlah pertanyaan lebih dari 6 pertanyaan 2 siswa, siswa yang tidak bertanya 8 siswa. Siklus II dengan jumlah pertanyaan lebih dari 6 pertanyaan 4 siswa tidak bertanya 5 siswa. Siklus III dengan jumlah pertanyaan lebih dari 6 pertanyaan 8 siswa tidak bertanya 1 siswa.

Berdasarkan data tersebut, dapat diketahui bahwa keaktifan bertanya dapat meningkat melalui model inkuiri terbimbing dilihat dari persentase siswa yang memenuhi indikator kinerja penelitian dari siklus I-III. Hasil penelitian ini memperkuat penelitian yang dilakukan oleh Pramesti (2015:95) penerapan model pembelajaran inkuiri dapat meningkatkan keaktifan bertanya dan diskusi siswa.

Berdasarkan hasil penelitian yang telah dicapai, peneliti mengajukan saran sebagai berikut: (1) bagi siswa sebaiknya siswa memiliki rasa ingin tahu yang tinggi dan aktif dalam pembelajaran sehingga pembelajaran menjadi interaktif dan memperoleh hasil yang maksimal, (2) bagi guru yaitu guru lebih cermat dalam memanfaatan waktu pembelajaran ketika menggunakan model inkuiri terbimbing dan memotivasi siswa untuk lebih aktif ketika pembelajaran, (3) bagi sekolah yaitu sekolah hendaknya dapat melengkapi sarana dan prasarana yang dapat menunjang proses pembelajaran, sehingga pembelajaran berjalan lancar, aktif, dan bermakna, (4) bagi pembaca/peneliti lain hendaknya membuat kegiatan pembelajaran yang lebih inovatif dan kreatif yang disesuaikan dengan perkembangan ilmu pengetahuan dan teknologi. Seperti halnya menggunakan model inkuiri terbimbing dalam pembelajaran.

\section{DAFTAR PUSTAKA}

Amir,M.F. (2015).Proses Berpikir Kritis Siswa Sekolah Dasar dalam Memecahkan Masalah Berbentuk Soal Cerita Matematika Berdasarkan Gaya Belajar.Jurnal Math Educator Nusantara, 01 (02),159-170.Diperoleh pada 17 Maret 2019, dari ojs.unpkediri.ac.id

Anam,K. (2016).Pembelajaran Berbasis Inkuiri:Metode dan Aplikasi.Yogyakarta: Pustaka Pelajar.

Arikunto,S. (2013).Penelitian Tindakan Kelas.Jakarta:Bumi Aksara.

Hapsari, D.P., Sudarisman, dan Marjono.(2012).Pengaruh Model Inkuiri Terbimbing Dengan Diagram V (Vee) dalam Pembelajaran Biologi terhadap Kemampuan Berpikir Kritis dan hasil Belajar Siswa.Pendidikan Biologi,4 (3) 16-28. Diperoleh pada 17 Maret 2019, dari jurnal.fkip.uns.ac.id.

Majid,A. (2017).Strategi Pembelajaran.Bandung:Remaja Rosdakarya. Metaputri,N.K.,Margunayasa,I.G., dan Garminah,N.N.(2016).Pengaruh 
model Pembelajaran Inkuiri Terbimbing dan Minat Belajar Terhadap Keterampilan Proses Sains pada Siswa Kelas IV SD. E-Journal PGSD Universitas Pendidikan Ganesha, 4 (1) 1-10. Diperoleh pada 17 Maret 2019, dari ejournal.undiksha.ac.id.

Pramesti,L.Y. (2015).Penerapan Model Pembelajaran Inkuiri untuk Meningkatkan Keaktifan Bertanya dan Berdiskusi Siswa Kelas X MIA 3 SMA Negeri 7 Surakarta Tahun Pelajaran 2014/2015. Skripsi Tidak Dipublikasikan.Universitas Sebelas Maret Surakarta, Surakarta.

Rusman. (2014). Model-Model Pembelajaran:mengembangkan profesionalisme guru.Jakarta:Raja Grafindo Persada.

Sagala,S. (2014). Konsep dan Makna Pembelajaran : untuk Membantu Memecahkan Problematika Belajar dan Mengajar.Bandung:Alfabeta.

Sugiyono. (2017) Metode Penelitian Kuantitatif, Kualitatif, dan R\&D.Bandung:Alfabeta. 